\title{
CYFROWE ARCHIWUM ŁODZIAN MIASTOGRAF.PL I BRONOWICKIE ARCHIWUM SPOŁECZNE - STUDIUM PORÓWNAWCZE DWÓCH CYFROWYCH ARCHIWÓW SPOŁECZNYCH
}

\section{Słowa kluczowe}

archiwa społeczne; badania terenowe; Cyfrowe Archiwum Łodzian; Miastograf; Bronowickie Archiwum Społeczne; studium przypadku

\section{Keywords}

community archives; field studies; Digital Łódź Citizens Archive; Miastograf; Community Archive of Bronowice; case study

\section{Streszczenie}

Artykuł jest studium porównawczym dwóch cyfrowych archiwów społecznych (Cyfrowego Archiwum Łodzian Miastograf.pl oraz Bronowickiego Archiwum Społeczne-

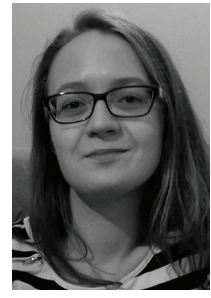

Magdalena Wiśniewska-Drewniak, magister archiwistyki i zarządzania dokumentacją, obecnie doktorantka na Wydziale Nauk Historycznych Uniwersytetu Mikołaja Kopernika w Toruniu. Jej zainteresowania badawcze to teoria archiwalna, historia mówiona w archiwach i archiwa społeczne. Temu ostatniemu zagadnieniu poświęcone są badania, które mają zakończyć się powstaniem rozprawy doktorskiej. Jej artykuły są publikowane na łamach czasopism archiwistycznych, m.in. „Archiwisty Polskiego". E-mail: magwis@doktorant.umk.pl. 
go) na podstawie badań terenowych tychże archiwów przeprowadzonych w ramach strategii studium przypadku. Autorka w skrócie prezentuje zastosowaną metodologię, przebieg badania oraz wykorzystane źródła (wywiady, obserwacje, artykuły naukowe i prasowe, strony internetowe i profile na portalach społecznościowych, dokumentacja urzędowa uzyskana w ramach dostępu do informacji publicznej). W dalszej części tekstu autorka zwraca uwagę na ujawniające się dzięki porównaniu zebranych danych podobieństwa oraz różnice między dwoma inicjatywami. Wśród podobieństw wymienia rodzaj gromadzonych przez archiwa materiałów (historie mówione w oryginale i kopie innych materiałów, zwł. fotografii), lokalna tematyka zasobów oraz wpływ specyfiki miejsca na kształt archiwum, a także realizowane cele społeczne i projektowy charakter działalności. Wśród różnic autorka zauważa odmienne sposoby gromadzenia, opisywania i udostępniania materiałów oraz archiwistyczne przygotowanie koordynatorki Bronowickiego Archiwum Społecznego.

O to chodziło właśnie - żeby nadać miastu kontekst, nadawać mu tożsamość... no i cały czas o to chodzi.

Michał Gruda,

Cyfrowe Archiwum Łodzian Miastograf.pl

- Co było najpierw - pomyst, żeby to zarchiwizować,

bo jest to coś interesującego, co się nie zachowa,

czy właśnie te społeczne cele?

- Wiesz co, dla mnie to było jakby równolegle.

Bo ja chyba do tej pory $w$ tej archiwistyce społecznej

dostrzegam doskonate narzędzie do pracy

ze społecznościami lokalnymi.

Natalia Martini,

Bronowickie Archiwum Społeczne

(0)

tym, czym są archiwa społeczne, polska naukowa literatura z zakresu archiwistyki powiedziała już niemało${ }^{1}$, choć wcale nie oznacza to, że na końcu drogi (bo i do tego końca daleko!) pojawiła się zgoda co do kształtu

1 M.in.: T. Czarnota, Komu sq potrzebne społeczne archiwa? „Archiwista Polski”, 2011, nr 4, s. 15-32; tenże, Problemy polskich archiwów społecznych za granica, [w:] Arkhivy Rossii i Pol'shi: istoriya, problemy i perspektivy razvitiya = Archiwa Rosji i Polski: historia, problemy i perspektywy rozwoju, red. L. Mazur i Y. Losovski, Jekaterinburg 2013, s. 145-160; tenże, O archiwach społecznych $i$ ich znaczeniu dla polskiego dziedzictwa narodowego oraz tożsamości lokalnej, „Archiwa - Kancelarie - Zbiory”, nr 5 (7), 2014, s. 126-129; K. Ziętal, Wstęp, [w:] Archiwistyka społeczna, red. K. Ziętal, Warszawa 2012, s. 9; M. Wiśniewska, Postmodernizm a archiwa społeczne, „Archiwista Polski”, 2013, nr 2, s. 27; taż, Archiwum społeczne - archiwum emocji, [w:] Toruńskie konfrontacje archiwalne, t. 4: Nowa archiwistyka - archiwa i archiwistyka $w$ ponowo- 
naukowej, archiwistycznej definicji tego typu archiwum² ${ }^{2}$. Ujęciem w językowe ramy tego różnorodnego zjawiska zajmują się również praktycy w dziedzinie oddolnego dokumentowania, tj. przede wszystkim Fundacja Ośrodka KARTA, która obecnie posługuje się następującą definicją archiwum społecznego:

Archiwum społeczne powstaje w efekcie celowej oddolnej działalności obywatelskiej. Jego główną misją jest aktywne działanie na rzecz ratowania i ochrony dziedzictwa kulturowego, a celem - pozyskiwanie, zabezpieczanie, opracowanie i udostępnianie materiałów wchodzących w skład niepaństwowego zasobu archiwalnego ${ }^{3}$.

Ponieważ definicja jest dość ogólna, a jednocześnie w odpowiedni sposób przedstawiająca istotę tego jakże różnorodnego zjawiska, jest w zupełności wystarczająca na potrzeby tego tekstu, zwłaszcza że jego tematem nie jest przecież dyskusja nad kształtem rozumienia tego terminu.

Wytłumaczyć się muszę również z zawartego w tytule artykułu określenia „cyfrowe archiwum społeczne”. Dróg rozumienia tego terminu może być kilka, podobnie jak sposobów czy poziomów „cyfrowości” społecznego archiwum ${ }^{4}$. Dwie wspomniane w tytule inicjatywy dokumentacyjne, które są przedmiotem niniejszego tekstu, zostały przeze mnie nazwane cyfrowymi archiwami społecznymi, ponieważ po pierwsze, wpisują się w przyjęte przeze mnie rozumienie terminu „archiwum społeczne”, a po drugie, ich działalność dokumentacyjna oparta jest o materiały cyfrowe; w obu przypadkach są to zarówno dokumenty born-digital (historie mówione i fotografie), jak i materiały wtórnie cyfrowe (skany dokumentów oryginalnie analogowych).

Celem niniejszego artykułu jest, z jednej strony, krótkie zaprezentowanie metodologii użytej w badaniach terenowych tytułowych archiwów społecznych, z drugiej zaś - przedstawienie Cyfrowego Archiwum Łodzian Miasto-

czesnym kontekście kulturowym, red. W. Chorążyczewski, W. Piasek, A. Rosa, Toruń 2014, s. 78.

${ }^{2}$ Choć są i tacy autorzy, którzy przekonani są o tym, że w temacie definicji terminu „archiwum społeczne” powiedziano już dość. Por. W. Chorążyczewski, Archiwa społeczne jako fenomen kulturowy, [w:] Archiwa organizacji pozarządowych w Polsce, red. T. Czarnota, M. Konstankiewicz, Warszawa-Lublin 2015, s. 21.

${ }^{3}$ Definicja archiwum społecznego, http://archiwa.org/as_definicja.php (dostęp: 27 II 2016 r.). Tam również dostępne są poprzednie definicje używane przez Ośrodek KARTA.

${ }^{4}$ M. Wiśniewska, Digital community archives, „Archiwa - Kancelarie - Zbiory”, nr 6 (8), 2015, s. 222-223. 
graf.pl oraz Bronowickiego Archiwum Społecznego (BAS) na podstawie informacji zdobytych w wyniku tychże badań oraz porównanie tych dwóch inicjatyw - zaprezentowanie łączących je podobieństw oraz występujących między nimi różnic, przede wszystkim w perspektywie dalszych badań nad zjawiskiem oddolnego dokumentowania.

Badania terenowe, dzięki którym uzyskałam informacje użyte w niniejszym artykule, przeprowadzone zostały jako badania wstępne w ramach projektu badawczego polegającego na pozyskiwaniu danych o istniejących obecnie w Polsce archiwach społecznych poprzez wywiad, obserwację i analizę dokumentów zastanych oraz ich przetwarzaniu w ramach strategii badawczej case study ${ }^{5}$.

Badanie terenowe Cyfrowego Archiwum Łodzian Miastograf.pl odbyło się 5 XI 2015 r. w Miejskim Punkcie Kultury PREXER - UŁ w Łodzi. Osobą udzielająca mi informacji był Michał Gruda, członek Łódzkiego Stowarzyszenia Inicjatyw Miejskich Topografie, obecnie koordynator projektu (główna osoba zajmująca się archiwum). Oprócz dwuipółgodzinnego wywiadu z informatorem oraz obserwacji na miejscu, źródłami użytymi do analizy były również m.in. sprawozdania z działalności stowarzyszenia, wywiady z członkami stowarzyszenia publikowane $\mathrm{w}$ mediach, strona internetowa oraz profil inicjatywy na portalu Facebook, filmy publikowane w serwisie YouTube oraz artykuły popularnonaukowe dotyczące działalności archiwum.

Badanie terenowe drugiego analizowanego projektu, Bronowickiego Archiwum Społecznego, odbyło się 4 III 2016 r. w mieszkaniu informatorki (archiwum nie ma siedziby), Natalii Martini, która jest koordynatorką i pomysłodawczynią archiwum. W ramach tego studium przypadku dane uzyskano poprzez wywiad (trwający około półtorej godziny), obserwację oraz analizę źródeł takich jak: artykuły naukowe na temat archiwum zawarte w specjalnym numerze „Bronowickich Zeszytów Historyczno-Literackich”, artykuły i notatki informacyjne w mediach, strona internetowa i profil inicjatywy na portalu Facebook oraz dokumenty otrzymane od Ministerstwa Pracy i Polityki Społecznej w ramach dostępu do informacji publicznej (Towarzystwo Przyjaciół Bronowic, będące formalnie organizatorem archiwum, trzykrotnie było beneficjentem środków w ramach Funduszu Inicjatyw Obywatelskich - w latach 2014, 2015 i 2016).

${ }_{5}$ Na temat metodologii badania dokładniej taż, Badanie archiwów społecznych metoda wielokrotnego studium przypadku - metodologia, „Archiwista Polski”, 2016, nr 1, s. 39-53. 
Przeprowadzone $\mathrm{w}$ ramach badań terenowych wywiady miały charakter wywiadów częściowo ustrukturyzowanych, tj. istniał stworzony wcześniej scenariusz wywiadu, zawierający przykładowe pytania oraz zagadnienia poruszane w trakcie rozmowy, jednak nie był on ostatecznym wyznacznikiem kształtu wywiadu, którego przebieg był modyfikowany zależnie od tego, w jaki sposób przebiegała komunikacja, jakie po kolei pojawiały się wątki. W związku z tym mogła być zmieniana kolejność zadawania pytań, a także pojawiły się nowe pytania, których nie zakładano na etapie planowania badania ${ }^{6}$. Wywiad był, za zgodą osób go udzielających, nagrywany w formacie audio, a potem, w ramach przygotowania danych do analizy, transkrybowany, tj. przepisany do formatu tekstowego (co zresztą okazało się jednym z najbardziej czasochłonnych zadań wykonywanych w ramach całego badania). Do wywiadów zostały przeze mnie stworzone tzw. fiszki wywiadu, tj. narzędzie dokumentacji badania terenowego zawierające podstawowe informacje na temat przeprowadzonego wywiadu, które pomagają potem w organizacji bardzo dużej liczby danych zbieranych w tego typu badaniach. Fiszki zawierały m.in. informacje dotyczące badanego archiwum, osób uczestniczących w wywiadzie (badacza i informatora), miejsca i daty wywiadu czy sposobów zapisu danych.

Kolejną metodą uzyskiwania danych na temat badanych archiwów była obserwacja, która miała cechy obserwacji jawnej, bezpośredniej i nieuczestniczącej, tj. przeprowadzanej z perspektywy „gościa”. Trzeba w tym miejscu wspomnieć, że w przypadku archiwów (niemal) całkowicie cyfrowych dokonywana przeze mnie obserwacja miała dość specyficzny charakter, ponieważ polegała przede wszystkim na patrzeniu w ekran komputera, nie jednak swojego własnego, ale tego, na którym informator prezentował mi cyfrowe archiwum, w tym to, jakiego typu materiały są przechowywane, jak są opisywane, jakiego rodzaju pomoce archiwalne się stosuje itp. W przypadku BAS zapoznałam się również z papierowymi formularzami protokołu przekazania materiałów do archiwum oraz zgód podpisywanych przez świadka historii (były to zgody na udostępnianie nagranej relacji historii mówionej). Tego typu obserwacja była dokumentowana poprzez wykonywane przeze mnie fotografie (tylko w przypadku BAS) i wypełnianą papierową fiszkę obserwacji (podobną w swej

${ }^{6}$ Więcej o wywiadzie jako metodzie badawczej zob. S. Gudkova, Wywiad $w$ badaniach jakościowych, [w:] Badania jakościowe, t. 2: Metody i narzędzia, red. D. Jemielniak, Warszawa 2012, s. 111-129.

7 Więcej o obserwacji jako metodzie badawczej zob. J. Sztumski, Wstęp do metod i technik badań społecznych, Katowice 1995, s. 112-119. 
strukturze i celach do fiszki wywiadu). Ponadto w trakcie badania informatorzy byli proszeni o wysłanie mi w późniejszym terminie pocztą elektroniczną zrzutów ekranu oraz plików zawierających informacje o sposobach przechowywania i opisywania zbieranych przez archiwum materiałów. W przypadku archiwów społecznych przechowujących również tradycyjne dokumenty obserwacja może zapewnić dane dotyczące również takich zagadnień jak np. sposób organizacji pracowni naukowej, sposób sygnowania archiwaliów i opisywania teczek, kształt tradycyjnych (papierowych) pomocy informacyjnych czy warunki magazynowe. Ponieważ jednak oba badane archiwa posiadają materiały wyłącznie elektroniczne, które są udostępniane tylko on-line, wymienione przed chwilą tematy nie znalazły pokrycia w zebranych danych.

Po badaniu terenowym i zebraniu dodatkowych źródeł (tj. materiałów publikowanych oraz dokumentów uzyskanych w ramach dostępu do informacji publicznej), dane zostały przygotowane do analizy (w tym dokonana została wspomniana już transkrypcja wersji audio wywiadów), zakodowane (tj. podzielone na tematyczne kategorie) ${ }^{8}$ oraz ustrukturyzowane $\mathrm{w}$ ramach przygotowanego wcześniej formularza raportu ze studium przypadku ${ }^{9}$, który umożliwia porównywanie ze sobą poszczególnych kategorii tematycznych (np. gromadzenie zasobu archiwalnego, podejmowane działania edukacyjne czy osoby zaangażowane w prace archiwum) w ramach różnych archiwów społecznych ${ }^{10}$.

Widoczną już na pierwszy rzut oka wspólną cechą łączącą Miastograf i BAS jest charakter zasobu determinowany przez rodzaj gromadzonych materiałów. Oba archiwa opierają się na wywoływanych historiach mówionych (będących materiałami cyfrowymi born-digital) oraz cyfrowych kopiach papierowych oryginałów. W przypadku Miastografu są to przede wszystkim fo-

8 J. W. Creswell, Projektowanie badań naukowych. Metody jakościowe, ilościowe i mieszane, przekł. J. Gilewicz, Kraków 2013, s. 201-205.

9 M. Wiśniewska, Badanie archiwów społecznych, s. 48-50.

${ }^{10} \mathrm{~W}$ tym miejscu zobowiązana jestem wspomnieć, że w momencie pisania tego artykułu analiza danych dot. Cyfrowego Archiwum Łodzian Miastograf.pl została już sfinalizowana, tzn. końcowy raport uzyskał akceptację osoby udzielającej informacji na temat archiwum, natomiast analiza danych dot. Bronowickiego Archiwum Społecznego jest w fazie końcowej, tzn. stworzony został roboczy raport ze studium przypadku, który nie został jeszcze przedstawiony informatorce do ostatecznego zatwierdzenia. 
tografie i pocztówki oraz w dużo mniejszym stopniu wycinki prasowe ${ }^{11}$. BAS natomiast skanuje i udostępnia również innego typu dokumenty, np. świadectwa szkolne, legitymacje, dowody osobiste, akty notarialne ${ }^{12}$, choć i w tym przypadku główną grupę kopiowanych źródeł stanowią fotografie. Zarówno Miastograf, jak i BAS to archiwa właściwie wyłącznie cyfrowe, które przechowują tylko materiały elektroniczne i z zasady nie mają intencji, aby tworzyć „fizyczne” archiwum. Jedyne papierowe materiały, poza bieżącą dokumentacją związaną z prowadzeniem archiwum, to zgody podpisywane przez świadków historii udzielających wywiadów wcielonych do zasobu archiwum ${ }^{13}$ oraz w przypadku BAS, protokoły przekazania materiałów do archiwum (wraz $\mathrm{z}$ opisem archiwalnym sporządzonym razem z ofiarodawcą) i deklaracje dotyczące praw autorskich przekazywanych materiałów ${ }^{14}$. Celowo oddzielam tutaj te materiały od bieżącej dokumentacji prowadzonej w związku z działalnością dokumentacyjną. Mimo że nie są to bezpośrednio materiały historyczne, będące częścią zasobu archiwalnego danego archiwum społecznego, to zapewniają one możliwość archiwizacji i udostępniania archiwaliów, czy obecnie, przez dane archiwum społeczne, czy też w przyszłości, np. przez archiwum państwowe czy muzeum, które przejmie zasób tegoż archiwum. Ze względu więc na skomplikowaną materię prawną związaną z posiadanymi $\mathrm{w}$ zasobie materiałami takie zgody i deklaracje nie są przeze mnie w tym miejscu traktowane jako dokumentacja bieżąca, a raczej dokumentacja będąca w tym momencie bliższa materiałom historycznym, zapewnia bowiem możliwość ich udostępniania przez archiwum i jest ich nieodłącznym składnikiem.

Kolejną cechą łączącą te dwa archiwa społeczne jest ich tematyka, obie inicjatywy dotyczą bowiem historii lokalnej i są ściśle związane ze specyfiką miejsca, w którym powstały i którego historię opisują.

Głównym tematem zasobu Miastografu jest Łódź - to, jak wygląda obecnie, oraz to, jak się zmieniała i wciąż zmienia na przestrzeni czasu. Szczególnie interesująca jest dla twórców archiwum „nieoficjalna” historia miasta, tj. ta opo-

11 Por.: Wycinki prasowe, http://miastograf.pl/search?press=true oraz Zdjęcia, http://miastograf.pl/search?image=true; stan na 17.09.2016 r., odpowiednio 9 i 2246 (dostęp: 17 IX 2016 r.).

12 Archiwum Prywatne Magdaleny Wiśniewskiej-Drewniak (dalej APMW-D), Wywiad z Natalią Martini. Rozmowę przeprowadziła Magdalena Wiśniewska. Kraków, 4 III $2016 \mathrm{r}$.

13 Tamże, Wywiad z Michałem Grudą. Rozmowę przeprowadziła Magdalena Wiśniewska. Łódź, 5 XI 2015 r.; Wywiad z Natalią Martini.

14 Wywiad z Natalią Martini. 
wiadana przez zwykłych mieszkańców, a nie przez celebrytów, oficjeli czy instytucje. Łódź jest miastem zmieniającym się bardzo szybko, co ma związek z tematyką zasobu archiwum (tj. opisaniem miasta - stąd nazwa Miastograf). Nie bez znaczenia są również drastyczne zmiany, które zaszły w tkance miasta zwłaszcza w latach 60. XX w. - część starszych mieszkańców wciąż pamięta kształt miasta sprzed modernizacji, w przeciwieństwie do młodszej części miejskiej społeczności. Lata 2007-2008 (a więc moment powstania stowarzyszenia) były okresem masowego wyjazdu Polaków zagranicę. Stowarzyszenie Topografie w pewnym stopniu powstało w odpowiedzi na to zjawisko - na negatywne opinie wielu młodych łodzian na temat ich miasta, problemy z tożsamością mieszkańców oraz poczucie braku historii miejsca, z którą mogliby się identyfikować ${ }^{15}$. Pomysł związany był też z przeświadczeniem twórców, że mimo popularności zjawiska wymieniania się kopiami starych fotografii w Internecie (w tym na portalu Facebook) oraz rosnącego zainteresowania historią lokalną, brak jakiejś inicjatywy, która zbierałaby w jednym miejscu najbardziej interesujące materiały; brak narzędzia, które służyłoby kompleksowemu oraz wygodnemu dokumentowaniu historii miasta. Jednocześnie twórcy stowarzyszenia uznali, że instytucje państwowe (tj. archiwa i muzea) skupiają się na dokumentowaniu historii miasta bez brania pod uwagę historii jego mieszkańców, nie dokumentując tym samym tego, co osobiste, codzienne i związane z doświadczaniem Łodzi ${ }^{16}$.

BAS dokumentuje historię Bronowic Małych, niegdyś podkrakowskiej wsi, będącej uposażeniem kościoła Mariackiego w Krakowie, a obecnie części Dzielnicy VI Bronowice. Wieś tę szczególnie upodobali sobie krakowscy artyści i literaci okresu Młodej Polski, kiedy to panowała tzw. ludomania, czyli zainteresowanie folklorem i codziennym, prostym życiem mieszkańców wsi. To w Bronowicach właśnie odbyło się w 1900 r. wesele Lucjana Rydla i Jadwigi Mikołajczykówny, opisane przez Stanisława Wyspiańskiego ${ }^{17}$. W $1941 \mathrm{r}$. Bronowice Małe zostały włączone w obręb Krakowa - wtedy właśnie zaczęły się drastyczne zmiany w tkance tego miejsca, przede wszystkim szybka urba-

15 A. Pawłowska, Zakorzenić łodzian w Łodzi, http://warszawa.naszemiasto.pl/archiwum/zakorzenic-lodzian-w-lodzi,1691562,art,t,id,tm.html (dostęp: 18 III 2016 r.).

${ }^{16}$ Miastograf | Cyfrowe Archiwum Łodzian [film w serwisie YouTube], https:// www.youtube.com/watch?v=bSxnue9NqVk (dostęp: 18 III 2016 r.); Wywiad z Michałem Grudą.

17 M. Wąchała-Skindzier, Życie codzienne $w$ Bronowicach Małych $w$ świetle wspomnień najstarszych mieszkańców, „Bronowickie Zeszyty Historyczno-Literackie”, z. 32, 2014, s. 19. 
nizacja, zmiana struktury ludnościowej (napływ nowych mieszkańców), zanik kultury rolnej i wiejskiej obyczajowości ${ }^{18}$. Mimo tych głębokich zmian, których doświadczyły Bronowice w XX w., mieszkańcy dzielnicy wciąż czują pewną odrębność, specyficzną bronowicką tożsamość, mówiąc np. że idą „do Krakowa”19, a „bronowicki krajobraz wciąż odsyła nas do wiejskiego rodowodu tego obszaru i jego barwnej historii" ${ }^{20}$. Jednocześnie Bronowice przeżywają zanik tożsamości opartej na wiejskim charakterze tego miejsca, w związku z postępującą modernizacją, wzrostem mobilności społecznej, zmniejszającym się przywiązaniem do miejsca zamieszkania i zanikającym międzypokoleniowym transferem wiedzy i doświadczeń ${ }^{21}$. Wciąż jeszcze żyją jednak mieszkańcy Bronowic, którzy pamiętają czasy, kiedy zamiast bloków z okien widać było pola, a w najbliższej okolicy pasło się krowy ${ }^{22}$. BAS powstało po to, aby zachować obraz dawnych Bronowic, zapisany jeszcze w pamięci najstarszych mieszkańców i posiadanych przez bronowian dokumentach z ich prywatnych archiwów. Zawiera przede wszystkim źródła do historii życia codziennego Bronowic, obrzędowości i zwyczajów, wierzeń i guseł, ale także topografii i zmian w lokalnym krajobrazie ${ }^{23}$.

W przypadku obu tych inicjatyw dokumentacyjnych widać więc wpływ specyfiki miejsca na decyzję o powstaniu archiwum oraz na jego tematykę. Twórcy Miastografu i BAS wskazują, z jednaj strony, na szybkie zmiany zachodzące w danym miejscu (odpowiednio - Łodzi i Bronowicach), z drugiej natomiast, na zanik tożsamości lokalnej i poczucia przynależności do miejsca, które są z kolei tych zmian efektami. Nie sposób nie wspomnieć w tym miejscu o francuskim historyku Pierze Norze ${ }^{24}$ i opisanym przez niego zjawisku przyśpieszenia historii, kiedy poczucie coraz szybciej oddalającej się przeszło-

18 Tamże, s. 32.

19 Tamże, s. 29.

20 N. Martini, Bronowickie Archiwum Społeczne, „Bronowickie Zeszyty Historyczno-Literackie", z. 32, 2014, s. 17.

21 APMW-D, Oferta organizacji pozarządowej realizacji zadania publicznego składana w 2014 r. na podstawie programu Fundusz Inicjatyw Obywatelskich na lata 2014-2020 pt. „Bronowickie Archiwum Społeczne”, sekcja II.2. (dokument otrzymany od Ministerstwa Pracy i Polityki Społecznej w ramach dostępu do informacji publicznej); N. Martini, dz. cyt., s. 12-13.

22 APMW-D, Oferta organizacji pozarządowej realizacji zadania publicznego składana w 2014 r., sekcja III. 7.

23 M. Wąchała-Skindzier, dz. cyt., s. 20.

${ }^{24}$ O którym zresztą już pisałam w kontekście archiwów społecznych. Por. M. Wiśniewska, Archiwum społeczne - archiwum emocji, s. 79, 85. 
ści i nagle następującej zmiany popycha ku dokumentowaniu ${ }^{25}$. Podobieństwo tych dwóch archiwów społecznych w tej materii, czyli w kwestii związku miejsca (i utożsamiania się z nim) z podjęciem decyzji o tworzeniu oddolnego archiwum, wydaje mi się bardzo interesujące, a przyjrzenie się temu zagadnieniu np. w kontekście innych archiwów społecznych o lokalnym charakterze może okazać się ciekawym i płodnym kierunkiem badań nad oddolnymi inicjatywami dokumentacyjnymi w Polsce.

W tym miejscu wspomnę tylko krótko, że na etapie planowania badania zakładałam, że taki związek może się pojawić. W związku z tym opracowując metodologię badania archiwów społecznych w modelu raportu z przypadku zawarłam punkt $2 \mathrm{c}$ - „Lokalizacja i teren działania (jeśli to możliwe, również ujęcie specyfiki miejsca)"26, inspirując się (nie tylko zresztą w tym miejscu) kształtem raportu stosowanego przez Community Archives Development Group w badaniach wpływu wywieranego przez brytyjskie archiwa społeczne, prowadzonych w latach 2006-200727.

W związku ze wspomnianym przywiązaniem do miejsca oraz poczuciem potrzeby ratowania lokalnej tożsamości, wyłania się kolejna cecha łącząca Miastograf i BAS, czyli realizowane przez te inicjatywy cele społeczne.

Nazwa „Miastograf” nawiązuje do głównego celu stowarzyszenia, czyli do opisania Łodzi, umożliwienia wirtualnego poruszania się po mieście i odczytywaniu go na wielu poziomach, tj. nie tylko poprzez warstwę historyczną, faktograficzną, ale też poprzez spojrzenie w jego klimat i „duszę”. Tym samym twórcy chcieli nadać miastu nowy kontekst oraz budować jego tożsamość w przekonaniu, że mieszkańcy Łodzi mają z tą tożsamością problem ${ }^{28}$. Miastograf ma być również narzędziem, dzięki któremu mieszkańcy Łodzi uświadomią sobie wartość swoich domowych archiwów - nie tylko dla historii ich czy ich rodziny, ale również dla dziejów miasta i jego tożsamości. Ma budzić

25 P. Nora, Czas pamięci, przekł. W. Dłuski, „Res Publica Nowa”, lipiec 2001, s. 39-40.

${ }^{26}$ M. Wiśniewska, Badanie archiwów społecznych, s. 48.

${ }^{27}$ Krótkie podsumowanie badania: Summary, http://www.communityarchives. org.uk/content/resource/summary (dostęp: 19 IX 2016 r.); przykładowy raport ze studium przypadku: CADG: Community Archives Impact Study: Case Study No. 3: Eastside Community Heritage, http://www.communityarchives.org.uk/wp-content/uploads/2014/05/Community_Archives_Case_Study_Eastside_CH_final_May_07_rev.pdf (dostęp: 19 IX 2016 r.).

${ }^{28}$ APMW-D, Oferta organizacji pozarządowej realizacji zadania publicznego „Wspieranie działań archiwalnych 2016” pt. „Rozwój i profesjonalizacja Cyfrowego Archiwum Łodzian Miastograf.pl", sekcja III.2 (dokument otrzymany od Naczelnego Dyrektora Archiwów Państwowych w ramach dostępu do informacji publicznej). 
przekonanie, że domowe zdjęcia oraz osobiste wspomnienia są narodowym dziedzictwem kulturowym ${ }^{29}$. Archiwum jest środkiem służącym popularyzacji tych materiałów, dzięki czemu zapoznać się z nimi mogą setki czy nawet tysiące osób, a nie tylko najbliższa rodzina. Kolejnym celem istnienia Cyfrowego Archiwum Łodzian jest zwrócenie uwagi władz miejskich na wartość zabytkowej łódzkiej zabudowy Śródmieścia, a także obudzenie w młodych łodzianach zainteresowania lokalną historią, obudzenie w nich lokalnej tożsamości, a w konsekwencji stworzenie poczucia, że warto dbać o swoje miasto ${ }^{30}$.

Głównym celem przyświecającym BAS jest „pielęgnacja bronowickiej tożsamości kulturowej poprzez ocalenie od zapomnienia i promocję lokalnego dziedzictwa kulturowego" oraz aktywizacja i integracja członków lokalnej społeczności ${ }^{31}$. Lokalne zasoby kulturowe (czyli w tym wypadku wywoływane przez archiwum historie mówione oraz kopiowane dokumenty) mają w założeniu służyć promocji dzielnicy, a także działać w kierunku zaangażowania bronowian na rzecz lokalnego dobra wspólnego ${ }^{32}$. Nie bez znaczenia jest również spowodowanie sytuacji, w której ułatwia się międzypokoleniowy transfer wiedzy (na temat historii i zwyczajów Bronowic Małych) oraz integrację między pokoleniami ${ }^{33}$; procedury BAS zakładają bowiem, że dwiema głównymi grupami zaangażowanymi w tworzenie archiwum są ludzie młodszego pokolenia (poniżej 26 roku życia), którzy są społecznymi archiwistami m.in. nagrywającymi wspomnienia i skanującymi dokumenty, oraz osoby starsze (powyżej 65 roku życia), które są skarbnicami tych informacji - posiadaczami wspomnień i wiedzy o dawnych Bronowiacach oraz dokumentów na ich temat. W efekcie program BAS ma również pogłębić wśród bronowickiej mło-

${ }^{29}$ Miastograf | Cyfrowe Archiwum Łodzian.

30 Wywiad z Michałem Grudą; A. Pawłowska, dz. cyt.

31 Stąd też finansowanie inicjatywy przez Ministerstwo Pracy i Polityki Społecznej. Zob. Oferta organizacji pozarządowej realizacji zadania publicznego składana w 2014 r. na podstawie programu Fundusz Inicjatyw Obywatelskich na lata 2014-2020 pt. „Bronowickie Archiwum Społeczne”, sekcja III.1.

32 Tamże, sekcja II.2; APMW-D, Oferta organizacji pozarządowej realizacji zadania publicznego składana w 2014/2015 r. na podstawie programu Fundusz Inicjatyw Obywatelskich - konkurs FIO 2015 pt. „Bronowickie Archiwum Społeczne Plus” (dokument otrzymany od Ministerstwa Pracy i Polityki Społecznej w ramach dostępu do informacji publicznej, sekcja III.6; APMW-D, Oferta organizacji pozarządowej realizacji zadania publicznego składana w 2015/2016 r. na podstawie programu Fundusz Inicjatyw Obywatelskich - konkurs FIO 2016 pt. „Bronowickie Archiwum Społeczne rozwój i popularyzacja zasobu" (dokument otrzymany od Ministerstwa Pracy i Polityki Społecznej w ramach dostępu do informacji publicznej), sekcja III.2 i III.6.

${ }^{33}$ N. Martini, dz. cyt., s. 13-15. 
dzieży zainteresowanie lokalną historią i przywiązanie do „małej ojczyzny”"34. Aktywizacji lokalnej społeczności oraz popularyzacji bronowickiego dziedzictwa kulturowego służyć ma również podejmowane przez BAS w 2016 r. społeczne opisywanie treści poprzez wspólne opracowanie archiwaliów w trakcie spotkań (przede wszystkim najstarszych) bronowian, zwieńczone zaplanowaną przez uczestników tych spotkań wystawą archiwalną ${ }^{35}$.

Może więc to właśnie jest kluczem do zrozumienia istoty oddolnego dokumentowania? Próbowaliśmy szukać powodu, dla którego archiwa tego typu nazywać można społecznymi. Odpowiedzią nie była ani społeczna własność zasobów, bo taka istnieć nie moż $\mathrm{e}^{36}$, ani zaangażowanie w sprawę społeczności czy też wytworzenie się wokół archiwum jakiegoś typu społeczności, bo to nie wydaje się konieczne (np. w przypadku inicjatyw dokumentacyjnych jedno- czy dwuosobowych, a jednak nie prywatnych, tylko szeroko udostępnianych). Być może archiwa są społeczne, bo spełniają cele społeczne i to tego typu cele stoją w centrum istoty ich funkcjonowania, determinują powód ich powstania oraz podejmowane działania. Naturalnie jest to wyłącznie pewien koncept, który wymaga rozwinięcia, ale i daje do myślenia, również w perspektywie tworzenia naukowej definicji tak różnorodnego zjawiska jak oddolne dokumentowanie.

Jest jeszcze jedna cecha, która łączy BAS i Miastograf. Tą cechą jest projektowy charakter działalności. Oznacza to, że żadne z tych archiwów nie ma stałego finansowania, a środki pojawiają się tylko w wypadku, gdy prowadząca dane archiwum organizacja pozarządowa (odpowiednio: Towarzystwo Przyjaciół Bronowic i Łódzkie Stowarzyszenie Inicjatyw Miejskich Topografie) otrzyma zewnętrzne środki na prowadzenie swojej archiwalnej działalności. Na przestrzeni kilku lat swojego funkcjonowania Miastograf był wspierany przez różnego rodzaju instytucje, w ramach różnorodnych programów; były to Unia Europejska - program „Młodzież w działaniu”, Narodowy Instytut Au-

34 Oferta organizacji pozarządowej realizacji zadania publicznego składana w 2014 r. na podstawie programu Fundusz Inicjatyw Obywatelskich na lata 2014-2020 pt. „Bronowickie Archiwum Społeczne”, sekcja III.6.

35 Oferta organizacji pozarządowej realizacji zadania publicznego składana w 2015/2016 r. na podstawie programu Fundusz Inicjatyw Obywatelskich - konkurs FIO 2016 pt. „Bronowickie Archiwum Społeczne - rozwój i popularyzacja zasobu”, sekcja III.8, działania 9-11; Nowy projekt, http://archiwumbronowickie.pl/2016/05/09/ nowy-projekt-2/ (dostęp: 20 IX 2016 r.); Powiedz, co wiesz o Bronowicach!, http://archiwumbronowickie.pl/2016/06/16/powiedz-co-wiesz-o-bronowicach/ (dostęp: 20 IX 2016 r.).

36 T. Czarnota, Komu sa potrzebne społeczne archiwa? 
diowizualny, Muzeum Historii Polski - program „Patriotyzm jutra”, Fundacja Orange - program „Akademia Orange”, Ministerstwo Kultury i Dziedzictwa Narodowego - konkurs „Aktywność bywatelska” i „Kultura ludowa i tradycyjna", Urząd Miasta Łodzi oraz Stowarzyszenie Naukowe Collegium Invisible ${ }^{37}$. BAS dotowane było natomiast trzykrotnie (w latach 2014, 2015 i 2016) przez Ministerstwo Pracy i Polityki Społecznej w ramach programu „Fundusz inicjatyw obywatelskich" (priorytet: aktywne społeczeństwo, kierunek działania: aktywizacja obywateli w sprawach wspólnotowych) ${ }^{38}$. Oba stowarzyszenia ubiegały się również o środki w ramach konkursów dotacyjnych ogłoszonych przez Naczelnego Dyrektora Archiwów Państwowych ${ }^{39}$.

Zauważenie tego projektowego (grantowego) charakteru działalności archiwów społecznych nie jest jednak niczym nadzwyczajnym, wiele tego typu inicjatyw żyje w ten sposób od lat, pozyskując środki z różnych źródeł, przede wszystkim od instytucji państwowych i samorządowych, ale nie tylko. Nie oznacza to jednak, że archiwa społeczne działają tylko w okresach otrzymywania dotacji, a w momentach ich braku całkowicie przestają funkcjonować. Wydaje się, że raczej istnieją i działają cały czas, lecz w momentach otrzymywania zewnętrznych funduszy ich działania stają się bardziej żywiołowe, archiwa te mogą na chwilę „rozwinąć skrzydła” zgodnie z celami i efektami zakładanymi w realizowanym wniosku; tak jest przynajmniej w przypadku Miastografu i BAS. Natalia Martini, koordynatorka tego drugiego, mówi o tej sytuacji następująco: „są okresy po prostu między projektami, gdzie archiwum nie umiera wcale na ten czas, ja się tego bardzo bałam, że między kolejnymi dotacjami to nie będzie żyło..." ${ }^{\prime 40}$.

37 Wywiad z Michałem Grudą.

38 Wyniki konkursu FIO w 2014 r.: Priorytet 2 projekty roczne, http://www.pozytek.gov.pl/Wyniki,konkursu,FIO,2014,3555.html (dostęp: 30 VII 2016 r.); Wyniki konkursu FIO w 2015 r.: Priorytet 2 projekty roczne, http://www.pozytek.gov.pl/Wyniki,konkursu,3680.html (dostęp: 30 VII 2016 r.); Wyniki konkursu FIO w 2016 r.: Priorytet 2 projekty roczne, http://www.pozytek.gov.pl/Wyniki,konkursu,FIO,2016,3877.html (dostęp: 30 VII 2016 r.).

39 APMW-D, Oferta organizacji pozarządowej realizacji zadania publicznego „Wspieranie działań archiwalnych 2016” pt. „Rozwój i profesjonalizacja Cyfrowego Archiwum Łodzian Miastograf.pl” (dokument otrzymany od Naczelnego Dyrektora Archiwów Państwowych w ramach dostępu do informacji publicznej); APMW-D, Oferta organizacji pozarządowej realizacji zadania publicznego „Wspieranie działań archiwalnych 2016” pt. „Bronowickie archiwum społeczne - opracowanie i udostępnienie zasobu" (dokument otrzymany od Naczelnego Dyrektora Archiwów Państwowych w ramach dostępu do informacji publicznej).

40 Wywiad z Natalią Martini. 
Czy odpowiedzią na tę niepewną finansową sytuację archiwów społecznych są dotacje Naczelnego Dyrektora Archiwów Państwowych w ramach konkursów pt. „Wspieranie działań archiwalnych”? Tylko częściowo. Jest to po prostu kolejny projekt, w ramach którego tego typu inicjatywy mogą uzyskać zewnętrzne finansowanie. Jak prawie każdy projekt grantowy jest on organizowany tylko raz na jakiś czas, nabór wniosków nie jest realizowany w trybie ciągłym; jest projektem zadaniowym, a nie możliwością uzyskania stałego finansowania (np. na bieżące materiały służące archiwizacji, utrzymanie magazynów czy hosting stron internetowych). Nie zmienia to naturalnie faktu, że program ten został stworzony po to, aby być pomocą dla archiwów społecznych (i innych przechowawców ewidencjonowanego niepaństwowego zasobu archiwalnego); jest jednak kolejnym czynnikiem utrwalającym projektowe finansowanie i tego typu inicjatyw i ich skokową intensyfikację działalności, która zresztą nie musi być koniecznie postrzegana jako zjawisko wyłącznie negatywne, dopóki nie doprowadza do sytuacji, kiedy między projektami istnienie inicjatywy oraz bezpieczeństwo gromadzonych materiałów są zagrożone.

Oprócz podobieństw udało mi się dostrzec także różnice między Miastografem i BAS. Pierwszą z nich jest sposób gromadzenia materiałów, choć w kilku jego punktach znów będę musiała powołać się najpierw na podobieństwa. Relacje oral history, w jednym i w drugim przypadku, gromadzone są przez osoby współpracujące $\mathrm{z}$ archiwum. W przypadku Miastografu są to członkowie stowarzyszenia mający naukowe przygotowanie do nagrywania historii mówionej (metoda biograficzna) ${ }^{41}$. W przypadku BAS nagrania realizowane są przez osoby, które wcześniej przeszły kurs z archiwistyki społecznej, w ramach którego poruszano również zagadnienia związane z metodologią i techniką prowadzenia tego typu wywiadów ${ }^{42}$. Oba archiwa społeczne wchodzą w posiadanie kopii dokumentów tradycyjnych przy okazji nagrywania wywiadów ze świadkami historii, skanując posiadane przez nich materiały, które są następnie włączane do archiwum ${ }^{43}$. W przypadku Miastografu warto jednak wspomnieć również o stronie internetowej www.miastograf.pl, która oprócz

41 Wywiad z Michałem Grudą.

42 Oferta organizacji pozarządowej realizacji zadania publicznego składana w 2014 r. na podstawie programu Fundusz Inicjatyw Obywatelskich na lata 2014-2020 pt. „Bronowickie Archiwum Społeczne”, sekcja III.3 i III.8; Oferta organizacji pozarządowej realizacji zadania publicznego składana w 2014/2015 r. na podstawie programu Fundusz Inicjatyw Obywatelskich - konkurs FIO 2015 pt. „Bronowickie Archiwum Społeczne Plus", sekcja III.8.

43 Wywiad z Michałem Grudą; Wywiad z Natalią Martini. 
pełnienia funkcji „wyjścia” dla materiałów posiadanych przez archiwum, czyli bycia medium służącym udostępnianiu źródeł historycznych i ich popularyzacji, miała z założenia być również kanałem ich „wejścia” do archiwum. Użytkownicy po zalogowaniu się na stronie Miastografu (przez serwisy Facebook lub Google+) mogą dodawać materiały na stronę (przede wszystkim fotografie), tworzyć lub zmieniać ich opis, a także je komentować. Wbrew założeniom twórców ta społecznościowa funkcja portalu używana jest jednak rzadko, a większość materiałów została zamieszczona on-line przez członków stowarzyszenia ${ }^{44}$. Różnica jest więc właściwie tylko pozorna i na poziomie założeń. Miastograf stosuje jednak jeszcze inną drogę gromadzenia kopii fotografii, a jest to współpraca z instytucjami publicznymi. W ten sposób do Cyfrowego Archiwum Łodzian trafiło prawie 1000 fotografii posiadanych przez biuro Miejskiego Konserwatora Zabytków, wypożyczonych Stowarzyszeniu Topografie w ramach współpracy z Urzędem Miasta Łodzi celem stworzenia kopii. Stowarzyszenie samodzielnie sporządziło ich opis oraz wykonało cyfrowe kopie, a następnie oddało konserwatorowi oryginały wraz z ich cyfrowymi odwzorowaniami ${ }^{45}$.

Kolejną różnicą jest sposób prezentowania posiadanych przez te archiwa społeczne materiałów w Internecie, przede wszystkim, jeśli chodzi o historię mówioną. Miastograf prezentuje on-line krótkie fragmenty audio (niekiedy nawet kilkunastosekundowe $)^{46}$, pochodzące $\mathrm{z}$ wywiadów trwających około trzech godzin, a także krótkie fragmenty transkrypcji tych wywiadów. W przyszłości twórcy archiwum planują przypisać te fragmenty do konkretnych miejsc na mapie Łodzi, która to mapa jest centralnym punktem strony internetowej ${ }^{47}$. Na stronie BAS można natomiast zapoznać się z większymi fragmentami wywiadów historii mówionej, dochodzącymi długością nawet do około godziny (choć są i takie trwające tylko kilka minut), a także z wyodrębnionymi z całości ludowymi przyśpiewkami, kolędami ${ }^{48}$ oraz wierszami.

Każde z opisywanych przeze mnie archiwów społecznych wytworzyło specyficzną dla siebie formę tworzenia opisów archiwalnych, nie dopatrywałabym się jednak w tej kwestii do końca różnicy, a właściwie raczej wspólnej

44 Wywiad z Michałem Grudą.

45 Tamże.

46 Zob. np. Poznańska - ulica dzieciństwa [fragment wspomnień Edwarda Mullera], http://miastograf.pl/asset/82 (dostęp: 20.09.2016 r.)

47 Wywiad z Michałem Grudą.

48 Wspomnienia Anieli Mtynarczyk, http://archiwumbronowickie.pl/2014/09/17/ wspomnienia-aniela-mlynarczyk-z-d-jasinska/ (dostęp: 20.09.2016 r.). 
cechy w postaci stworzenia własnego standardu postępowania z dokumentacją i własnego systemu pomocy informacyjnych ${ }^{49}$. Kwestia ta jest dość skomplikowana i obszerna, w tym miejscu chciałabym ją poruszyć tylko pobieżnie.

Wymienić można trzy narzędzia opisu materiałów z Miastografu wytworzone przez twórców archiwum: fiszka z opracowanego przez Stowarzyszenie Topografie podręcznika do historii mówionej (zawierająca m.in. informacje na temat przeprowadzonego wywiadu, udzielającego go świadka historii oraz treści zawartych $\mathrm{w}$ wywiadzie) ${ }^{50}$, lista rozmówców (prowadzona w dostępnym dla twórców archiwum pliku arkusza kalkulacyjnego, zawiera również informacje dot. wywiadów historii mówionej, w tym informacje o charakterze bardziej zmiennym i praktycznym, np. czy już wykonano transkrypcję wywiadu, wypełniono fiszkę, napisano biogram świadka lub czy fragmenty wywiadu zostały użyte na wystawie ${ }^{51}$ oraz rejestr fotografii od Miejskiego Konserwatora Zabytków (zawierający szczegółowy opis fotografii zeskanowanych dzięki współpracy z biurem konserwatora, w tym miejsce wykonania fotografii, słowa kluczowe, rozdzielczość skanu) ${ }^{52}$.

W przypadku BAS główną pomocą archiwalną jest inwentarz zasobu w pliku arkusza kalkulacyjnego, który składa się z dwóch części. Pierwszą z nich jest zakładka zatytułowana „Inwentarz zasobu”, drugą - zakładki odpowiadające poszczególnym teczkom (choć „teczki” w BAS są tylko pewnym konstruktem informacyjnym, bo archiwum jest, jak wspominałam, wyłącznie cyfrowe i fizycznie tradycyjnych teczek nie posiada). Zakładka „Inwentarz zasobu” zawiera stosowane w tym archiwum nazwy określające części zasobu wraz z ich rozumieniem; są to:

- ZASÓB - ogół archiwaliów będących w posiadaniu Bronowickiego Archiwum Społecznego

49 W kwestii opisu archiwalnego stosowanego przez archiwa społeczne sytuacja w ostatnim czasie zmienia się bardzo dynamicznie, ze względu na wprowadzenie przez Ośrodek KARTA Otwartego Systemu Archiwizacji dla archiwów społecznych. Przedstawione $\mathrm{w}$ tym miejscu informacje dotyczą stanu przed rozpoczęciem używania tego systemu przez opisane archiwa, a więc dostarczają wiedzy na temat oryginalnych rozwiązań stosowanych przez archiwistów społecznych w momencie przeprowadzania badań terenowych.

${ }^{50}$ Historie mówione - podręcznik, oprac. M. Welfe, red. J. Czurko, A. Zysiak, Łódź 2010, s. 15.

51 APMW-D, Lista rozmówców - Archiwum Pamięci Łodzian. Zrzut ekranu przesłany przez Michała Grudę.

52 APMW-D, Miastograf - rejestr fotografii. Zrzut ekranu przesłany przez Michała Grudę. 
- DZIAŁ - nadrzędna jednostka kategoryzacyjna

- ZESPÓŁ - grupa archiwaliów w obrębie działu wyodrębniona ze względu na rodzaj/temat/osobę

- TECZKA - grupa archiwaliów w obrębie zespołu wyodrębniona ze względu na rodzaj/temat/osobę/czas

- DOKUMENT - najmniejsza jednostka kategoryzacyjna (plik) ${ }^{53}$.

Dział wyodrębniono do tej pory jeden, „Kolekcje osobiste”, i oznaczono go cyfrą rzymską I. W skład zasobu wchodzą ponadto 23 zespoły, każdy nazwany od imienia i nazwiska darczyńcy. Każdy zespół składa się z teczek, od jednej do trzech. Teczki natomiast odzwierciedlają podział ze względu na formę; osobne są teczki dla relacji świadków historii, dla fotografii i dla pozostałych rodzajów dokumentów (a właściwie - dla kopii wykonanych z posiadanych przez świadków oryginałów) $)^{54}$.

W tym miejscu warto zaznaczyć pewną cechę BAS (której jednocześnie nie można dostrzec z taką klarownością w Miastografie), tj. przygotowanie do prowadzenia archiwum osoby go koordynującej. Podział zasobu na zespoły według twórców archiwaliów, a także w ogóle użycie takich terminów jak „zasób” i „zespół” jest wynikiem samodoskonalenia się p. Natalii Martini w dziedzinie archiwistyki ${ }^{55}$. W trakcie wywiadu pojawia się zresztą więcej terminów z dziedziny, jak np. „metodyka opracowania archiwaliów”, „działalność informacyjna”, „pomoce archiwalne”, „materiały archiwalne”, „protokół zdawczo-odbiorczy"56. To, ilu archiwistów społecznych ma jakiekolwiek przygotowanie z zakresu archiwistyki i po co sięgają, chcąc zasięgnąć informacji o tym, jak zorganizować archiwum, również może być interesującą kwestią związaną z badaniem archiwów społecznych.

Miastograf i BAS nigdy blisko ze sobą nie współpracowały, choć oba archiwa są członkami Sieci Archiwów Społecznych zainicjowanej przez Ośrodek KARTA $^{57}$ oraz sygnatariuszami Karty Zasad Archiwów Społecznych ${ }^{58}$. Mimo to wykazują wiele cech wspólnych: są zainteresowane lokalnym kolorytem i przeszłością regionu, w którym działają, dokumentują historię codzienności,

53 APMW-D, BAS - inwentarz zasobu. Plik w programie Excel przesłany przez Natalię Martini.

54 Tamże.

55 Wywiad z Natalią Martini.

56 Tamże.

57 Sieć Archiwów Społecznych, http://archiwa.org/as_siec.php (dostęp: 20 IX 2016 r.).

${ }^{58}$ Karta Zasad Archiwów Społecznych, http://archiwa.org/as_karta_zasad.php (dostęp: 20 IX 2016 r.). 
mentalności i losy zwykłych ludzi, stosują w swoich działaniach ideę folksonomii, czyli społecznego opisywania treści, są projektami niemal wyłącznie cyfrowymi i opartymi na udostępnianiu posiadanych przez siebie materiałów w Internecie, a ich działalność ma charakter projektowy. W pewnych jednak kwestiach różnią się od siebie - każde z tych archiwów opisuje swój zasób w specyficzny dla siebie sposób (choć oba wytworzyły w tej materii pewne własne standardy), do pewnego stopnia odmiennie gromadzą i udostępniają swoje materiały. Fakt, że udało mi się porównać ze sobą te dwa archiwa na podstawie tak rozbudowanej bazy źródeł (kilkudziesięciominutowe wywiady, materiał z obserwacji, strony internetowe i serwisy społecznościowe, artykuły naukowe i prasowe, dokumentacja urzędowa, pomoce archiwalne, itd.), dowodzi według mnie, że przyjęta przeze mnie koncepcja „studiowania przypadków" i terenowego badania społecznych inicjatyw dokumentacyjnych zakończonego zestandaryzowanym raportem z pojedynczego przypadku, umożliwiającym porównywanie poszczególnych archiwów społecznych, sprawdza się i w związku z tym będzie w przyszłości kontynuowana.

\section{Archiwalia}

Archiwum Prywatne Magdaleny Wiśniewskiej-Drewniak

- Oferta organizacji pozarządowej realizacji zadania publicznego „Wspieranie działań archiwalnych 2016” pt. „Bronowickie archiwum społeczne - opracowanie i udostępnienie zasobu" (dokument otrzymany od Naczelnego Dyrektora Archiwów Państwowych w ramach dostępu do informacji publicznej)

- Oferta organizacji pozarządowej realizacji zadania publicznego „Wspieranie działań archiwalnych 2016” pt. „Rozwój i profesjonalizacja Cyfrowego Archiwum Łodzian Miastograf.pl" (dokument otrzymany od Naczelnego Dyrektora Archiwów Państwowych w ramach dostępu do informacji publicznej)

- Oferta organizacji pozarządowej realizacji zadania publicznego składana w 2014 r. na podstawie programu Fundusz Inicjatyw Obywatelskich na lata 2014-2020 pt. „Bronowickie Archiwum Społeczne” (dokument otrzymany od Ministerstwa Pracy i Polityki Społecznej w ramach dostępu do informacji publicznej)

- Oferta organizacji pozarządowej realizacji zadania publicznego składana w 2014/2015 r. na podstawie programu Fundusz Inicjatyw Obywatelskich - konkurs FIO 2015 pt. „Bronowickie Archiwum Społeczne Plus” (dokument otrzymany od Ministerstwa Pracy i Polityki Społecznej w ramach dostępu do informacji publicznej)

- Oferta organizacji pozarządowej realizacji zadania publicznego składana w 2015/2016 r. na podstawie programu Fundusz Inicjatyw Obywatelskich - konkurs FIO 2016 pt. „Bronowickie Archiwum Społeczne - rozwój i popularyzacja za- 
sobu" (dokument otrzymany od Ministerstwa Pracy i Polityki Społecznej w ramach dostępu do informacji publicznej)

- BAS - inwentarz zasobu. Plik w programie Excel przesłany przez Natalię Martini

- Lista rozmówców - Archiwum Pamięci Łodzian. Zrzut ekranu przesłany przez Michała Grudę

- Miastograf - rejestr fotografii. Zrzut ekranu przesłany przez Michała Grudę

- Wywiad z Michałem Grudą. Rozmowę przeprowadziła Magdalena Wiśniewska. Łódź, 5 XI 2015 r.

- Wywiad z Natalią Martini. Rozmowę przeprowadziła Magdalena Wiśniewska. Kraków, 4 III 2016 r.

\section{Literatura}

CADG: Community Archives Impact Study: Case Study No. 3: Eastside Community Heritage, http://www.communityarchives.org.uk/wp-content/uploads/2014/05/Community_Archives_Case_Study_Eastside_CH_final_May_07_rev.pdf (dostęp: 19 IX 2016 r.)

Chorążyczewski W., Archiwa społeczne jako fenomen kulturowy, [w:] Archiwa organizacji pozarzadowych $w$ Polsce, red. T. Czarnota, M. Konstankiewicz, Warszawa-Lublin 2015.

Creswell J. W., Projektowanie badań naukowych. Metody jakościowe, ilościowe i mieszane, przekł. J. Gilewicz, Kraków 2013.

Czarnota T., Komu sq potrzebne społeczne archiwa?, „Archiwista Polski”, 2011, nr 4.

Czarnota T., O archiwach społecznych $i$ ich znaczeniu dla polskiego dziedzictwa narodowego oraz tożsamości lokalnej, „Archiwa - Kancelarie - Zbiory”, nr 5 (7), 2014.

Czarnota T., Problemy polskich archiwów społecznych za granica, [w:] Arkhivy Rossii i Pol'shi: istoriya, problemy i perspektivy razvitiya = Archiwa Rosji i Polski: historia, problemy i perspektywy rozwoju, red. L. Mazur i Y. Losovski, Jekaterinburg 2013.

Definicja archiwum społecznego, http://archiwa.org/as_definicja.php (dostęp: 27 II 2016 r.).

Gudkova S., Wywiad w badaniach jakościowych, [w:] Badania jakościowe, t. 2: Metody i narzędzia, red. D. Jemielniak, Warszawa 2012.

Historie mówione - podręcznik, oprac. M. Welfe, red. J. Czurko, A. Zysiak, Łódź 2010.

Karta Zasad Archiwów Społecznych, http://archiwa.org/as_karta_zasad.php (dostęp: 20.09.2016 r.).

Martini N., Bronowickie Archiwum Społeczne, „Bronowickie Zeszyty Historyczno-Literackie", z. 32, 2014.

Nora P., Czas pamięci, przekł. W. Dłuski, „Res Publica Nowa”, lipiec 2001.

Nowy projekt, http://archiwumbronowickie.pl/2016/05/09/nowy-projekt-2/ (dostęp: 20 IX 2016 r.).

Pawłowska A., Zakorzenić łodzian w Łodzi, http://warszawa.naszemiasto.pl/archiwum/zakorzenic-lodzian-w-lodzi,1691562,art,t,id,tm.html (dostęp: 18 III 2016 r.)

Powiedz, co wiesz o Bronowicach!, http://archiwumbronowickie.pl/2016/06/16/powiedz-co-wiesz-o-bronowicach/ (dostęp: 20 IX 2016 r.). 
Poznańska - ulica dzieciństwa [fragment wspomnień Edwarda Mullera], http://miastograf.pl/asset/82 (dostęp: 20 IX 2016 r.).

Sieć Archiwów Społecznych, http://archiwa.org/as_siec.php (dostęp: 20 IX 2016 r.).

Summary, http://www.communityarchives.org.uk/content/resource/summary (dostęp: 19 IX 2016 r.).

Sztumski J., Wstęp do metod i technik badań społecznych, Katowice 1995.

Wąchała-Skindzier M., Życie codzienne w Bronowicach Małych w świetle wspomnień najstarszych mieszkańców, „Bronowickie Zeszyty Historyczno-Literackie”, z. 32, 2014.

Wiśniewska M., Archiwum społeczne - archiwum emocji, [w:] Toruńskie konfrontacje archiwalne, t. 4: Nowa archiwistyka - archiwa i archiwistyka $w$ ponowoczesnym kontekście kulturowym, red. W. Chorążyczewski, W. Piasek, A. Rosa, Toruń 2014.

Wiśniewska M., Badanie archiwów społecznych metoda wielokrotnego studium przypad$k u$ - metodologia, „Archiwista Polski”, 2016, nr 1.

Wiśniewska M., Digital community archives, „Archiwa - Kancelarie - Zbiory”, nr 6 (8), 2015.

Wiśniewska M., Postmodernizm a archiwa społeczne, „Archiwista Polski” 2013, nr 2.

Wspomnienia Anieli Młynarczyk, http://archiwumbronowickie.pl/2014/09/17/wspomnienia-aniela-mlynarczyk-z-d-jasinska/ (dostęp: 20 IX 2016 r.).

Ziętal K., Wstęp, [w:] Archiwistyka społeczna, red. K. Ziętal, Warszawa 2012.

\section{Inne}

Miastograf | Cyfrowe Archiwum Łodzian [film w serwisie YouTube], https://www. youtube.com/watch?v=bSxnue9NqVk (dostęp: 18 III 2016 r.).

Wycinki prasowe, http://miastograf.pl/search?press=true (dostęp: 17 IX 2016 r.).

Wyniki konkursu FIO w 2014 r.: Priorytet 2 projekty roczne, http://www.pozytek.gov. pl/Wyniki,konkursu,FIO,2014,3555.html (dostęp: 30 VII 2016 r.).

Wyniki konkursu FIO w 2015 r.: Priorytet 2 projekty roczne, http://www.pozytek.gov. pl/Wyniki,konkursu,3680.html (dostęp: 30 VII 2016 r.).

Wyniki konkursu FIO w 2016 r.: Priorytet 2 projekty roczne, http://www.pozytek.gov. pl/Wyniki,konkursu,FIO,2016,3877.html (dostęp: 30 VII 2016 r.).

Zdjęcia, http://miastograf.pl/search?image=true (dostęp: 17.09.2016 r.).

\section{Summary}

The Digital Archive of Łódź Citizens Miastograf.pl and the Community Archive of Bronowice - a comparative study of two digital community archives

The article is a comparative study of two digital community archives (the Digital Archive of Łódź Citizens Miastograf.pl and the Community Archive of Bronowice) based on field studies of these archives conducted as a part of case study strategy. The author shortly presents the methodology and course of the research, as well as sources used in it (interviews, observations, scientific and press articles, websites and social network pages, office records accessed as public information). Then the 
author shows similarities and differences between the two archives found thanks to comparison of the collected data. Among similarities she mentions the type of collected materials (oral histories in original and copies of other types of documents, especially photographs), local subject of the collections and impact of specific local characteristics to the shape of the archives, as well as social objectives and activity based on projects. Among differences she names various ways of acquiring, describing and providing access to the materials and archival knowledge of the coordinator of the Community Archive of Bronowice. 
